\title{
The Main Centers for Production of Enameled Pottery and Their Features
}

\author{
Najmeh Nouri ${ }^{1,}$, Fereshteh Sharifi ${ }^{2}$ \\ ${ }^{1}$ Faculty of Preservation and Restoration Department of Archaeology, Isfahan University of Art, Isfahan, Iran \\ ${ }^{2}$ Faculty of Art and Architecture Department of Archaeology, Bu-Ali Sina University, Hamedan, Iran
}

Email address:

noori_najmeh@yahoo.com (N. Nouri)

${ }^{*}$ Corresponding author

\section{To cite this article:}

Najmeh Nouri, Fereshteh Sharifi. The Main Centers for Production of Enameled Pottery and Their Features. International Journal of Archaeology. Vol. 4, No. 2, 2016, pp. 17-25. doi: 10.11648/j.ija.20160402.12

Received: April 29, 2016; Accepted: May 9, 2016; Published: May 20, 2016

\begin{abstract}
This project is about skills and ability of Iranian potters in producing porcelain enamel. Procedure of performing relief and decoration in manufacturing center contain characteristics that make different every center from other centers. The main question is that where the main centers of porcelain is enamel And what is basic property of porcelain enamel decoration in different city? Rey, Saveh, Sultan Abad and Kashan was the main centers of porcelain enameled. Gorgan, Neighbor and Tabriz are the other cities of manufacturing clay. Perhaps, Rey and Kashan manufactured clay for the same time $\mathrm{T}$ but pointers of Kashan was the best. In Kashan style in spite of Rey, the most important matter was descriptive forms and craftsman considered more attention to this. In Kashan group, statues was the biggest level and faces was impressive and decoration was disperse that is completely differ from Rey method. In Rey method of ten used from miniature design and in Kashan method used of calligraphy and designing for decorating clays. Pottery industry in Saveh is most important rival for Rey and Kashan, that this is not so differ from pottery in Rey and Kashan. in some dishes that produced by using of Saveh method, there is combination of Rey and Kashan method and can be said this is adoption of human body in Kashan style, but there is some intervention in state of human faces and decoration style in designing of cloths. Since, Saveh was heir apparent, developing of pottery in Soltan Abad is due to relation with Kashan. There is some advantages in Soltan Abad clays that contain: scant colures, accuracy of animal design, so that this is not so differ from natural forms and bowl dishes that is not common in other city. Soltan Abad glaze have more arch and garniture and impacts of china art was observed from Soltan Abad clay, also, human faces in this type of clay is look like mogul faces. Research method of this project is historical and look in sites carried out by using of internet and searching the foreign museums. The purpose of this research is to investigate main centers of manufacturing porcelain enameled and its property in each center.
\end{abstract}

Keywords: Pottery Enameled, Manufacturing Center, Features Index

\section{Introduction}

Guston Wiet was one of the first persons who studied in this field and introduced three primary enameled pottery vessels dated back to 1180,1183 , and $1228 \mathrm{AD}$ belonged to Khwarazmian Dynasty. Also Ettinghausen considered $1136 \mathrm{AD}$ as date of the oldest type of this vessel. Some of researchers analyzed this type of pottery about technique of producing this type of porcelain (Froom, 2008). At the same time, Karimi and Kiani have expressed classification and distinguishing of features of enameled pottery based on human, animal, and plant design themes with respect to historic preference (Karimi and Kiani, 1985). Some of experts have also dealt with the pottery galleries inside and outside the country (Pope, 2009; Zaki, 2009; Connell, 2008, Porter, 2002, Kiani, 1978) and have written some issues about physical features and decorations of this type of pottery (Pope, 2009; Grube, 1976; Fehervari, 1973) and compared them with each other in terms of production technique. Also, Bahrami has played essential role in identifying and introducing decorative features of enameled pottery vessels (Bahrami, 1948). Very marvelous enameled potteries have 
been acquired from Schmidt excavations in Rey zone where those artifacts are now placed in National Iranian Museum. Unfortunately, no report is available about this excavation. Similarly, no useful conclusion has been so far presented for recognizing centers for production of the enameled potteries as a monograph. Therefore, it seemed necessary to deal with features of these potteries at any center in addition to introduce the main centers of production for enameled potteries in a brief research. The method of this study is of descriptive- historic type of research and data collection was done by librarian technique.

The Seljuk Turks ruled over Iran from $11^{\text {th }}$ to $13^{\text {th }}$ AD centuries i.e. during two Seljuk and Khwarazmian Dynasties up to Mongol Invasion. The enamel pottery that is assumed as the most beautiful porcelains in Islamic Era has been invented at this period where it has high position in historic and artistic field in our country today. The period of Seljuk ruling has been one of the paramount historic periods in Islamic art and Persian literature. During this period, Book of Khamse of Nezami Ganjavi famous Iranian poet and Firdausi's Shahnameh Divan were versified where most of themes of these two works have been used as designs for potteries including story of Bahram Gur, Bijan and Manijeh, and heroisms of Fereidoon. On many occasions, the artists of this era have embodied and completed the arts belonged to the past periods particularly Sassanid. Seljuk Turks have been always influenced by climate of their governing zones and Iranian Seljuk has been impacted by Iranian ancient artists and culture. In addition, Seljuk was not sufficed with imitation from Iranian artifacts but they represented culture of Chinese's during their residing in their birthplace in Turkistan at Central Asia and learned a lot points from Uyquri tribes. Thus, the repeated influence has been created from penetration of culture from Central Asia in Iran.

With their beautiful color and designs, the enameled potteries have embodied the most accessible favorable perfection in Persian Art and decorations of these potteries show lofty order in design and painting that not only projected the needed effect on decoration but on development of Persian portraiture. Production of enameled vessels was mainly prevalent in Rey and Kashan and they have been made during $13^{\text {th }}$ century in Saveh and Sultan Abad cities as well. Of other major centers for production of enamel pottery one can refer to Gorgan, Neishabur, and Tabriz. At this era, the pottery craftsman has succeeded in integration of plant, animal, and human design with each other and creating balanced and harmonic composition and structure more than any other period. In order to identify taste and art of pottery designers in this study, the main centers for production of enameled pottery and prominent decorative features were explored at any center.

\section{Enameled Pottery}

Term 'Mina' with Arabic origin denotes enamel (Allen, 2008: 30). In some sources, term 'Mina' has been mentioned as very colorful and or seven-color as well (Porter, 2002: 17).
In fact, this type decoration is called over enameled decorations as well. It is assumed this glazing technique on pottery was invented by Persian people since samples of enameled vessels have not been found in any other place (Allen, 2008:5). The first case of using overlay gild pottery dated back to these enameled potteries in Iran. These vessels that belonged to Seljuk and Khwarazmian eras are characterized under title of enameled potteries or sevencolor vessels (Porter, 2002: 17; Fehervari, 1973: 40; Degeorge,2003: 46) and achieved perfection with experience resulting from development that emerged at the end of Seljuk era regarding pottery art and it was coincided with Sung Art in China (Karbasi; 2001: 2) and produced the revolution that occurred at $13^{\text {th }} \mathrm{AD}$ century and it was ceased in $14^{\text {th }}$ and $15^{\text {th }}$ AD centuries based on witting of Abolghasem Kashani (Allen, 2008: 44).

\subsection{Decoration Techniques of Enameled Pottery}

In this technique, pottery paste is changed in comparison to the former porcelains and Chinese paste or clay is starting to be used. The enameled potteries are made with a lot of care and intricacy. White opaque colors, pale blue, and turquoise were utilized for under-enameled color at first phase. Afterwards, during the next development period application of over enameled colors became prevalent such as indigo blue, green (Copper), brown (Ferro- manganese), turquoise, red, yellow (lead or antimony), white, black (Ferro- manganese), and golden. Sometimes these colors were placed together and made seven-color meaningful. Initially, the main body was cooked and body of vessels was a type of pottery called glass paste of stone-paste (fritware) that was prepared by quartz powder and clay (Chinese soil or kaolin is the best type of them) and other fillers (e.g. sodium, potassium, calcium, and magnesium). Technique used for this body was probably transferred from Syria and or Egypt to Iran (Froom; 2008: 91)

Since these are types of materials not available for Iranians and they were not assumed as followers of traditional and classic techniques of Iranians but it was an imitation from Chinese bodies. Iranian pottery started building this body when the lubricant and adhesive nature of enamel on this body and also their flexibility and strength influenced them and often molding was used for production of these bodies of stone-paste. After cooking the body of pottery, the background color was painted that was opaque white and or blue enamel and the vessel entered into the furnace for second time. At next steps, the enamels were placed in furnace at lower temperatures depending on type of used colors on enamel and of course their resistance against heat in various times. Similarly, some points were left on enamels for gilding on surface of them (Ibid: 81). In fact, pottery craftsmen had found that they might use two techniques to create enameled potteries with stable designs including either they could restrict painting to a few colors that might necessarily tolerate for cooking enamel of vessels at one phase and or after glazing of vessel they might cook them and then recook these vessel with unstable colors at lower 
temperatures in furnace (Karbasi, 2002: 3).

James Allen has assumed most of enameled vessels as gilded potteries (Allen, 2008: 27) (Figs 1 and 2). The gilding decorations were added on designs of vessel at final phase and or as laminated layer and or as color (Grube, 2005: 158). Abbasian has used term 'gold-coating' for the enameled vessels and considered enameled works as one of most difficult techniques of enamel in Iran (Abbasian, 2000: 47). The best samples of enameled potteries that have been made after Mongol Invasion included a lot of gilded parts and produced in Kashan. The method preparation of golden enamel for these vessels has been expressed by Abolghasem Abdullah Ibn Ali Ibn Mohammad Ibn Abitaher in a specific treatise about this technique titled book of (Jewel brides and refined precious objects). As a result, the gilded vessels manufactured in Kashan may be attributed to the end of $13^{\text {th }} \mathrm{AD}$ century (Firooz, 1966: 115; Kashani, 2007: 339).

We can observe this technique in some vessels such as ewer, tray, bowl, and jar and generally in vessels with everyday use. But, based on statement of Grube, the expensive decorations and delicate works in this group of vessels have converted them into the luxurious vessels but they were produced at large scale as if the manufacturers and consumers of these potteries were not afraid of delicacy and cost of these vessels (Grube, 1976: 196). These enameled vessels were the start point in gilding on enamel in Islamic world.

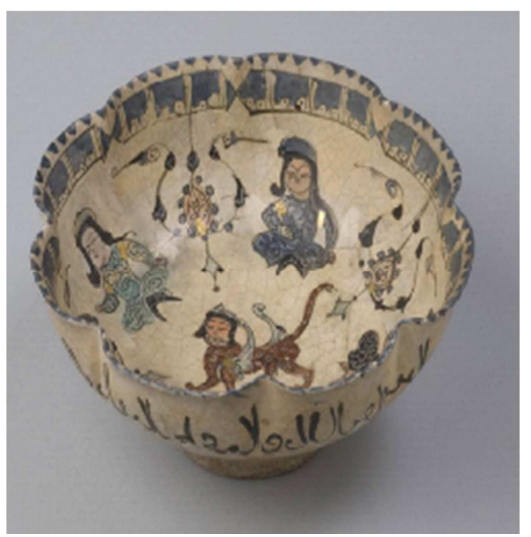

Fig. 1. The gilded enameled pottery, $14^{\text {th }}$ AD century, Rey (Philadelphia Museum).

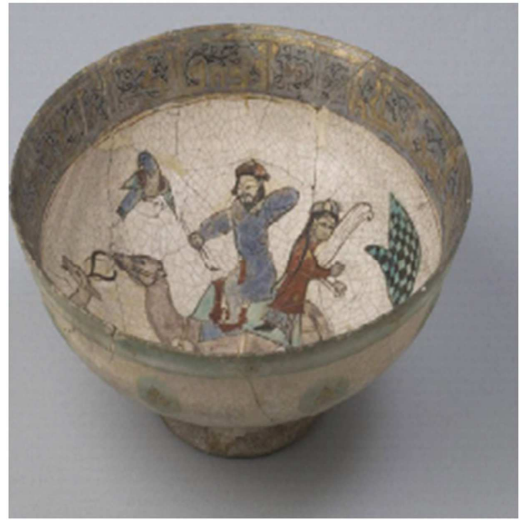

Fig. 2. The gilded enameled pottery, $14^{\text {th }}$ AD century, Saveh (Philadelphia Museum).

\subsection{The Embossed Enameled Potteries}

There are also some enameled potteries under title of embossed enameled vessels and or enameled ceramics as well with embossed and latticed parts of course the gilding part has been mainly focused on these parts of vessels. These vessels are the most lavish enameled vessels and thereby a new spirit was induced in body of embossment technique as Sassanid heritage and many special cups and vessels were manufactured that were decorated by gilded embossed works. There are also some samples that show development and magnificence of works from Rey pottery craftsmen. They tried to degrade value of Sung Porcelain and Tin-Yau Porcelain more than all by glass paste. In this way, some craftsmen have proposed some versions for making fimo (polymer clay) of porcelain in which the used materials were not too different from each other. In fact, a type of water clay mixture (Barbotine) was coated in surface of embossed areas after creating embossed parts and has provided suitable backgrounds for gilding and attaching gilded layers on the surface. These vessels generally belonged to $13^{\text {th }}$ and $14^{\text {th }} \mathrm{AD}$ centuries and they are called Barbotine potteries (Blaire and Bloom, 2003: 33; Connell, 2008: 90) (Fig 3). Production of these vessels was continued by early $14^{\text {th }} \mathrm{AD}$ centuries. The raised parts on this type of potteries are made of a material rather than the main material of body (Froom, 2008: 8). But, some experts argue that before the first phase of cooking, the latticed and embossed parts have formed of clay on their body and gilding of these vessels has made their production more complicated than ever (Karbasi, 2001: 5) (Fig 4).

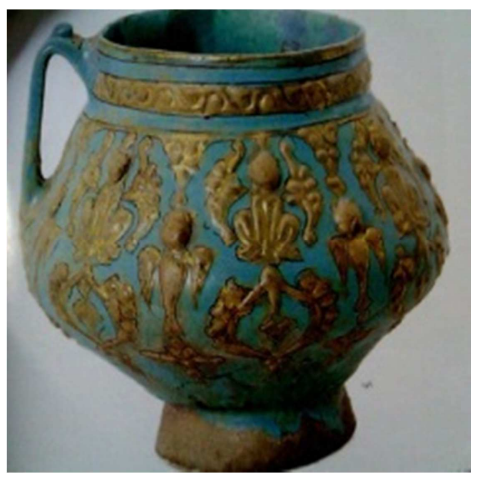

Fig. 3. The gilded enameled, $13^{\text {th }}$ and $14^{\text {th }}$ AD centuries, Iran (Grube, 2005 : 150).

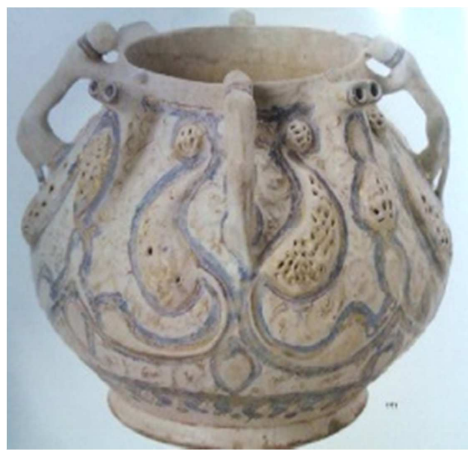

Fig. 4. The latticed enameled pottery, $13^{\text {th }}$ and $14^{\text {th }}$ AD centuries, Iran (Grube, 2005: 197). 


\section{The Production Centers of Enameled Pottery}

Rey, Saveh, Sultan Abad, and Kashan were some of main centers for production of enameled potteries (Kiani; 1978: 19-20). Also some calcimined Gorgan area as one of production centers for these potteries (Firooz, 1966: 109; Zaki, 2009: 157; Karbasi, 2001: 3). After Mongol Invasion to Shahr-E-Rey (Rey City), Kashan was converted into the main center for production of very fine gilded enameled potteries and Kashani family was deemed as one of the most well-known manufacturers of these vessels and they continued to production of enameled vessels by the middle era at Mongol period (Connell, 2008: 90). The Gorgan pottery masters followed local style and sometimes manipulated in that style. Some precious vessels were discovered in Gorgan that were relatively unique in terms of beauty and fineness. Gorgan not only imported these vessels from Rey and Kashan but also invited the master from those areas to attend and reside in Gorgan (Khamooshi, 2006: 86). Neishabur and Tabriz are also included in cities with pottery furnaces and workshop for the enameled pottery vessels. Some of pottery craftsmen of Kashan opened workshops in Tabriz and produced the enameled pottery there. Compare to Kashan potteries, Tabriz potteries are less fine in terms of body (Ibid: 86). We may see application of enameled work most frequently in vessels and in fact no specific sample using enameled work seen in buildings except some examples in Anatolia (porter, 2002: 39). Similarly, two square bricks called 'enameled tiles' are kept in museum of Arabic Artifacts Institute (Dar-Alasar Al Arabiya) in Cairo at Egypt (Zaki, 2009: 103). And also there is a noticeable sample of a piece of tile with twelve- arrow design that is one unit or a part of a regular and fully detailed design with established composition at the center of a warrior when struggling with a dragon (Skiers, 1995: 279).

\subsection{Analysis on Enameled Pottery Made in Rey}

Overall, miniature designs were mainly used in decoration of potteries in Rey style and at the same time design art and calligraphy were utilized for this purpose in Kashan. The most beautiful vessels made in Rey include embossed designs covered by arabesque nodes. They made design separately and decorated them with golden color and then attached it on surface of vessels and it was placed on a transparent white background (Fig 5). There are several enameled enamels with a very wide color range that are often decorated with abstract plant and arabesque designs in the embossed samples. It was prevalent to use Kofi letters (script) for decoration of edges of vessels at that period and sometimes the professional master were careful in drawing Kofi letters and scripts that could be legible and often drew them in such a way that was away from writing rules and they were only assumed as some shapes by which they decorated the vessel. Sometimes, they employed Muhaqqeq script in frieze around the vessel for decoration as well (Zaki,
1984: 200). The names of three craftsmen and artists have been inscribed on some of these vessels for which they were involved in creation of these works including: Ali Ibn Yousef, Abitaher Hossein, and Hossein who are some of pottery artists in this period. The Rey enameled potteries belonged to second half of $13^{\text {th }}$ and $14^{\text {th }}$ AD centuries (Ibid: 202-204). Some of these images are similar to miniature scenes and paintings in terms of portraiture and color painting so that it is supposed the painter artists were the same (Grube, 1976: 197).

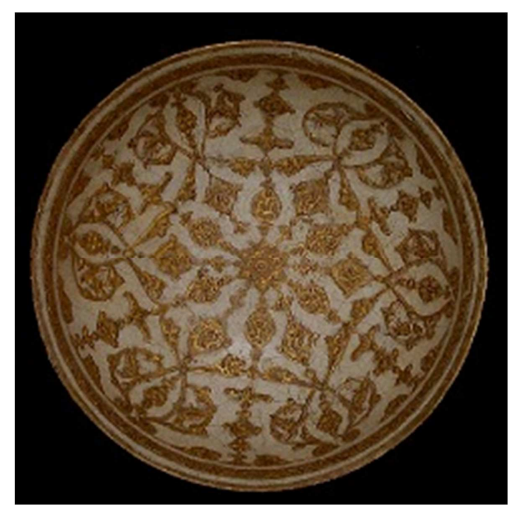

Fig. 5. Enameled bowl with geometric and floral elements design, end of $13^{\text {th }}$ and early $14^{\text {th }}$ AD centuries, Rey (Karbasi, 2001).

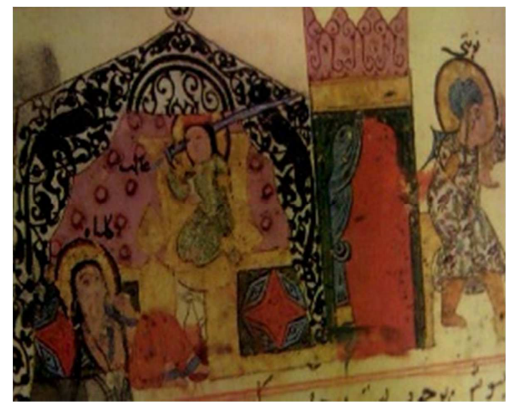

Fig. 6. The manuscript of paper and Golshah, 1264AD, Konya (Brand, 2004: 83).

One of the imaged versions that is available from the paintings in Seljuk era in $14^{\text {th }} \mathrm{AD}$ century in which miniature paintings and scenes of enameled seven colors on potteries have reflected harmony and mutual effect related to the Paper and Golshah as the most well-known one of these versions (Kambakhshfard, 2000: 262-264 \& Karbasi, 2001: 2) (Fig 6). The famous design of these vessels often includes epic scenes and sessions and historic myth at Sassanid era; some landscapes from Shahnameh such as story of Bahram Gur and Azadeh; of Nezami Quintet e.g. Love of Khosro to Shirin that have been utilized for decoration of many bowls and plates and they revived national traditions. The arabesque and plants designs concern with story related subjects, display royal court and enthroning of kings, royal chariot, accompaniment of attendants and musicians (dance and balling), formal feasts, design of rider in hunting with leopard or falcon, bow or spear, polo-players, royal entertainments, and princesses sitting on throne (Pope, 2008: 1873; Fehervari, 1973: 99). The decorative basis and material of enameled vessels produced in Shahr-ERey is a good-looking rider that sits on a beautiful and noble 
horse. Shahr-E-Rey pottery craftsmen have utilized geometric and plant figures (flower buds around design), shapes of rabbit, lion, terriers, image of camel and cameleer, and peacock in decoration of pottery industry as well (Zaki, 1984: 198; Kiani, 2000: 239-244) (Figs 7 and 8). In fact, mixing of various subjects in an arranged composition is traditional ancient continuity in Persian portraiture that had started already in Arsacid era. Likewise, details in pottery designs are similar to miniature e.g. type and form of characters, way of position and drawing of horses, floral elements decoration, the little birds sat on tress, and many features of embossed little designs and other drawing techniques (Pope, 2008: 1798).

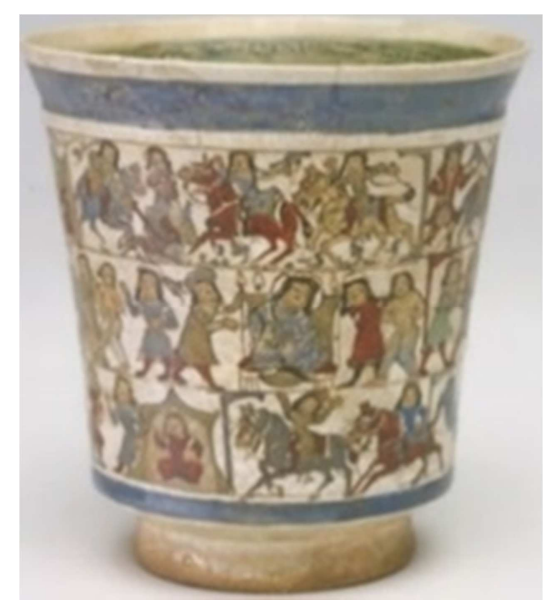

Fig. 7. Enameled pottery, story of Bijan and Manijeh, $13^{\text {th }}$ AD century, Rey (Freer Art Gallery).

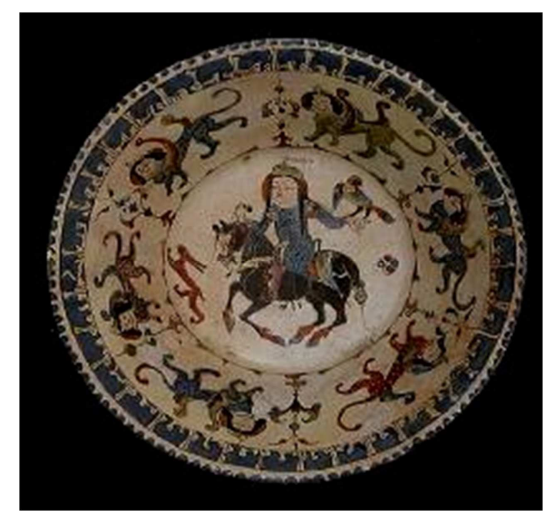

Fig. 8. The gilding enameled pottery, design of rider during riding and sphinx, $13^{\text {th }}$ and $14^{\text {th }}$ AD centuries, Rey (Metropolitan Museum).

The decoration on Rey vessels has not been perfectly filled and some parts of their surface have been created without design and some frames were built to separate designs (Kambakhshfard, 2000: 467). The background has been left with pale blue enamel and or beige tonality in all samples. The design has been usually molded and or completed by a frieze strip. In this type of design, calligraphy has been displayed with delicacy and edges have been often finished by spots and dents. Master Ali Ibn Yousef was proficient often in drawing small women while riding in chase and sitting on pony horses or design of happy and lively players (Pope, 2008: 1800). These sessions that have been excerpted from aristocratic life are usually restricted at margins in which design of Iranian classic animals was drawn (Fig 8). Also, similar cases are visible in weaving art as well. Rey masters were also skillful in making small pitchers. In these pitchers, a row of fantastic animals was drawn on a black strip on blue background (Pope, 2008: 105-109). The body of Rey enameled pottery is opaque and some various colors have been utilized in decoration of them such as azure, turquoise, pale violet, yellow, brown, pale and dark green, ocrea, and red (Khamooshi, 2006: 71). Similarly, color painting and composition of them was more important than shape and form of designs in Rey (Bahrami, 1948: 61).

\subsection{Analysis on Enameled Pottery Made in Kashan}

During $13^{\text {th }}$ to $19^{\text {th }}$ AD centuries, building of star shapes and large enameled pottery bricks was noticeably developed. On those ones who have built enameled bricks in Kashan one can refer to Abuzeid or Aburafzeh, Fakhreddin, and Jamaleddin. Rather than building of altars and tile bricks, Kashan pottery craftsmen have also made various highly beautiful and well-colored types of the enameled vessels (Zaki, 1984: 204-207).

Kashan craftsmen of enameled potteries have focused a lot of attention on drawing connected plants (arabesque) figures and covered background of their works often by precise figures of them and they have dealt with drawing branch and leaf of trees in curved queues and cypress tree on which some birds are visible. Most of subjects in figures of Kashan potteries are explanatory and the craftsman never pays more attention to some of these figures similar to Shahr-E-Rey pottery makers but he notices all of subjects that decorates it in an artifact he makes (Ibid, 207-211). The distinct features of designs in Kashan potteries are as follows: Linking of design in all points; dense adjustment, small docks, stripped and spotted leaves, and bearded gentlemen. The bodies are tended to occupy larger part of surface in Kashan pottery group. These designs encompass background and are integrated with it. The faces are noticeable that is completely unlike Rey style (Pope,2008: 1829-1830). In addition, faces are drawn exaggeratingly curved and raised in Kashan style and they show different face. The narrow eyes are drawn with a line to ear, the labyrinth loops of black hair, drawing of hands with forefinger that is taller exaggeratingly deemed as characteristic of this school (Pope, 2008: 1831).

The human bodies are often placed against a landscape in Kashan potteries and that landscape is composed of a tree and plant theme design. Sometimes one and or two bodies were drawn on potteries while sitting and talking to each other. The drawn eyes in bodies made the frown black brow more transparent (Katley and Hamby, 1997: 30). The craftsmen might start simultaneously producing enameled vessels in Kashan and Rey but the painters in Kashan have shown their superiorities soon. The famous samples of potteries in Kashan were made mainly in form of plate or cup. Image of hunting ground and musical sessions has been designed on many vessels but battlefields and seizure of castles were less visible on them (Bahrami, 1948: 74-75). 


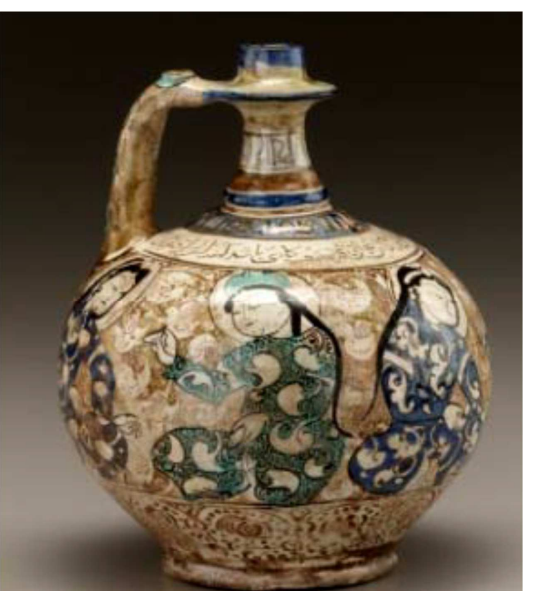

Fig. 9. Enameled jar, $13^{\text {th }} A D$, Kashan (Freer Art Gallery)

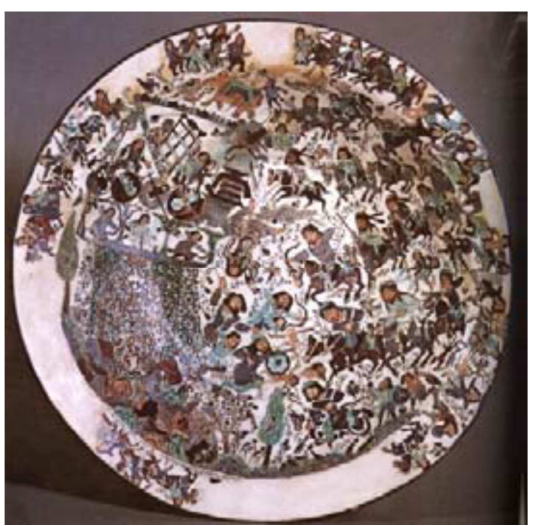

Fig. 10. Enameled bowl, $14^{\text {th }} A D$, Kashan (Freer Art Gallery).

In Rey style, it has been avoided from using of a lot of dense and compressed designs and major part of the background is blank without design in these vessels while in Kashan vessels, design of decorative themes are filled with dense and occupied design (Kiani \& Karimi, 1985: 50). The color composition is completely distinctive in Kashan style. The bright green, brown, and brownish red or chestnut colors were used in uniform tonalities and further resolution and homogeneity of tonality have been kept in sample of ShahrE-Rey work. However, dark purple color is found in Rey colors with difficulty. The other interesting feature is seen in link among background design and horse since scrolls of branch and leaf are directly linked with head of horse and its fast move and revived them. The cloth fiber of design is extraordinarily rich and very important source of information for synchronous fibers (Pope, 2008: 1832).

\subsection{Analysis of Enameled Pottery Made in Saveh}

Saveh city was considered as rival for Rey and Kashan cities in terms of pottery industry and technical methods used in this city are not too different from the method taken in Kashan and Rey cities. The Saveh pottery craftsmen have employed principles and materials and decorative elements in their industry for pottery vessels that were premium compared to pottery vessels made in Kashan and Rey cities and sometime they used group of them (Zaki, 1984: 216).
The subject of design and way of display of human's image in enameled potteries in Saveh have been derived from Kashan school, but way of decoration of cloth and face of persons signifies a new style that was prevalent there. One of the precious artifacts in Saveh city is a goblet in Oscar Rafael Gallery that indicates 1188AD and the image of a few women was drawn on it in a lush orchard versus Water Lake with several fishes floating there. Of other artifacts in this city is a ewer in Freer Art Gallery that is one of industrial products in $13^{\text {th }} \mathrm{AD}$ century and its images consists of a few woman and a duck with spotty feathers that is an evidence for existing strong relationship among pottery craft in Kashan and Saveh. Similarly, many enameled bowls have been found in Saveh that the internal part of them is covered by a flower similar to palmate imitated from vessels made in Rey (Ibid: 216). There a lot of potteries designed by image of animals in Saveh to the extent that it is supposed the animal design as one of features of artifacts made by craftsmen in this city (Pope, 2008: 110).

It is possible that the Saveh pottery craftsmen to work similar to the methods of their colleagues in Kashan and Rey (Zaki, 1984: 21). The important Saveh workshops have kept their activity and repute by second half of year 1188 AD. The best sample of Saveh artifact was made in Muharram month $1188 \mathrm{AD}$ and it is available in Alanbalesh gallery. The color composition of Saveh enameled vessels is similar to artifacts in Kashan and Rey. The proximity of two great national pottery manufacturing centers of course has impacted on taste and mind of Saveh pottery masters. The body of a horse rider is visible in Iranian Ancient Museum that has been made of blue pottery in Saveh by style of Chinese bodies belonged to Sung Dynasty of China. The mode of horse and hat are completely similar to original samples made in China (Bahrami, 1948: 89-90). Other designs of enameled potteries in Saveh city have been drawn by images of dialogue sessions, servants, cypress tree, water brook, row of birds, and branches and leaves (Ibid: 89). The manuscripts are coarser on internal surface of bowls and less smooth. Horse and body and edge strip have been drawn by Rey style. The color composition of Saveh enameled vessels include green, bright indigo, chestnut, and black on beige or turquoise background which are relatively unlike in Rey or Kashan works (Pope, 2008: 1859).

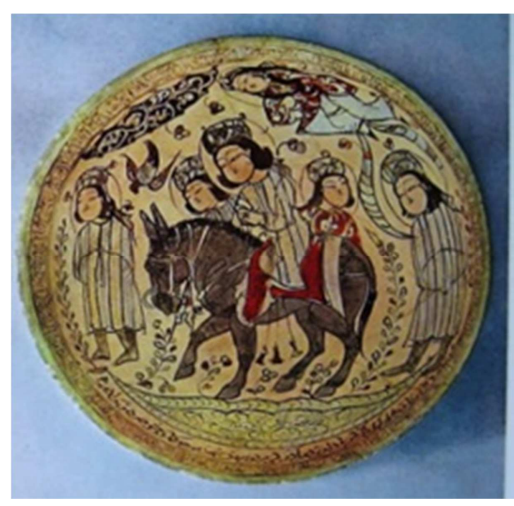

Fig. 11. Enameled pottery, dated 1136AD, Saveh (Pope, 2008: 686) 


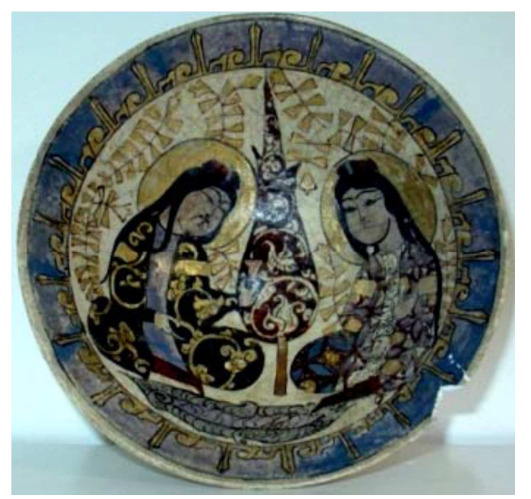

Fig. 12. Enameled gilding coated bowl, $14^{\text {th }} A D$ century, Saveh (National Iranian Museum).

\subsection{Analysis of Enameled Pottery Made in Sultan Abad}

As Saveh was deemed as superior heir for Rey works, Sultan Abad zone was also owed initially development of its pottery industry to relationship with Kashan (Pope, 2008: 1860). There were several cities and counties around Sultan Abad city in both $14^{\text {th }}$ and $15^{\text {th }}$ centuries where the pottery industry was noticeably popular there and excavation groups have explored a lot of potteries in ruined areas of these counties and they attributed them briefly to Sultan Abad city. A lot of samples have been found among these artifacts that may remind us of the potteries made in Kashan city but no sample of techniques of pottery production are seen from Shahr-E-Rey among them. The enamel of vessels belonged to Sultan Abad is more frequent than other types of Iranian potteries of this kind that displays rainbow color. The other advantage existing in Sultan Abad potteries is related to shape and appearance of the given vessels out of which there are figures of some of goblets that have not been prevalent and common in other cities and industrial centers in Iran (Zaki, 1984: 217). The advantage of potteries made in Sultan Abad compared to potteries from other centers is the limited colors and precision in drawing of animals and color distribution so that it is very difficult to distinguish the background color from color of figures and perhaps care and attention in drawing animals that do not differ from their natural shapes is one of the outcomes of influence by Far East (Ibid: 218). The Sultan Abad porcelain is premium in terms of purity of color and proportion as well. But no one could assume all attributed porcelains to this city and Shahr-E-Rey as industrial works that have been manufactured there since although these two cities were highly famous in middle centuries, it should not be forgotten that Kashan and Saveh and Neishabur were among important industrial centers (Ibid: 218).

The pottery producers in Sultan Abad have created beautiful enameled and bright porcelains so that it is a difficult task to distinguish them from the potteries in Kashan city (Ibid: 220). The most popular themes noticed by decorator of vessels were geometrical designs, figures of animals, birds, phoenix, and dragon and human around them some flower have been drawn and influence of Chinese art is visible in designs of Sultan Abad porcelains. The human's face is similar to Mongols in these potteries. Sultan Abad potteries are generally bright with slim body and designs of them were drawn on blue or gray background. Many wide branches and leaf have been used and more interestingly there is some deer with spotted skins there (Rafiyee, 1998: 160). The most popular colors in Sultan Abad style are white bud in dark background and narrow blue line (Pope, 2008: 11). The most beautiful of these designs belong to a small indented bowl that is placed in Emeryville where the wall of this bowl has been decorated with style of celadon vessels with some cracks and inside this bowl there is a citrus in which image of dialogue of a young person with an old man is displayed. But title of Sultan Abad is attributed mainly to other vessels that include sandy paste with white and uneven enamel. This is a color that covers so-called Sultan Abad pottery with rainbow mode and it is one of the most famous types of Persian potteries (Bahrami, 1948: 96).

\section{Conclusion}

Rey, Saveh, Sultan Abad, and Kashan were some of the main centers for production of enameled potteries. Gorgan, Neishabur, and Tabriz were also considered as areas for production of these potteries. The distinct features of enameled potteries in main production centers are as follows: many parts of these potteries lack design in Rey- made vessels. Miniature designs were mainly used in Rey style and design and calligraphy have been utilized for decoration of porcelains in Kashan. The famous design used in Rey-made vessels often included epic scenes and sessions, historic myths at Sassanid era, and story related subjects (scenes of Shahnameh and book of Nezami). Display of royal court, enthroning of rulers, royal chariot, accompaniment of retinues, sessions of dance and ball, formal feasts, royal entertainments, princesses sitting on throne, small ladies on riding horse, hunting by horse-riders (along with leopard or falcon, bow or spear), and images of polo-players were utilized for decoration of many bowls and plates. The pottery craftsmen have employed geometric and plant design figures (arabesque nodes and flower buds), animal figures (rabbit, lion, and terriers, design of camel with cameleer, peacock and mythical animals) in decoration at pottery industry. In this type of design, calligraphy is often finished by spots and dents (Kofi script, pseudo-Kofi, and Muhaqqeq script). Composition of colors was mainly important than figure and outlines of design in Rey style. The body of enameled pottery in Rey was opaque and several colors have been used in decoration including azure, turquoise, pale violet, yellow, brown, bright and dark green, ocrea and red, and golden colors.

Unlike Rey style in Kashan style subject of figures is explanatory. The distinct features of designs of Kashan potteries are as follows: Continuity of design, dense adjustment, drawing connected plant figures (arabesque) in background, stripped and spotted leave, trees branches and leaves in curved queues, scrolls of branch and leaf linking to horse design, cypress tree, small ducks, birds, bearded gentlemen, bodies with circular and raised faces, narrowed 
and drawn eyes, labyrinth loops of black hair and drawing tall forefinger, with scene of hunting ground and dancing sessions but battlefields and seizure of castle are less visible in them. The color composition is distinctive in Kashan style and comprises of bright green, brownish red or chestnut red and dark purple. In Kashan group, the bodies are tended to occupy greater part of surface and dense decorative have been designed that are totally different from Rey style.

Technical styles of pottery industry in Saveh city are not too different from Kashan styles and some of vessels include features both of Kashan and Rey works at the same time. The enameled bowls with a flower design similar to palmate are imitated from vessels made in Rey and spotted leaves are evident for relationship with Kashan pottery industry. The images of cypress tree, branches and leaves of trees, floating fishes, duck, row of birds, design of specific animals for craftsmen in this city, image of a woman beside orchard or brook, dialogue sessions, images of servants are some of designs used on Saveh enameled porcelains. Style of display of human bodies was inspired from Kashan school but mode of dressing and face makeup for individuals is new and in some cases horse body and its rider have been influenced by style of Chinese bodies as well. The colors used for these potteries including green, pale indigo, chestnut, and black on beige or turquoise background are relatively unlike Rey and Kashan styles.

The advantage of potteries made in Sultan Abad to porcelains from other centers is the limited colors and precision in drawing figures of animals so that they are not too different from their natural shapes which resulted from influence of Far East. The shape vessels are similar to goblets that have not been popular in other cities. The enamel of vessels belonged to Sultan Abad form rainbow color more than other types of colors. The most popular colors in Sultan Abad style is white bud in dark blue or gray background and the themes that have been noticed by potteries decorator include geometric designs, wide branches and leaves of trees, figures of animals, deer with spotted skins, birds, phoenix and dragon, human with surrounding flowers and dialogue sessions within citrus design. The influence of Chinese art is visible in Sultan Abad pottery designs and humans' faces are similar to Mongol pictures.

\section{References}

[1] Abbasian, M., (2000). Pottery and tiles in Iran's history, Tehran: Gothenburg

[2] Fairuz, Sh., (1966). Pottery, Tehran, Feb printing.

[3] Allen, J., (2008). Islamic pottery from the beginning to the patriarch. Translation: M. Shaysthfar. Tehran: Institute for Islamic Art.

[4] Atynghavzn, R. and Oleg Grabar., (2003). Islamic art and architecture (1). Translations, Jacob Azhand. Tehran: Organization of research Humanities Books.

[5] Askiers, J., (1995). Iranian Ceramic arts, collector W.
Ferreira. Translation Pervez border. Tehran: art collection. 271-294.

[6] Blair, Sh. and Jonathan M. blvm. (2003). Islamic art and architecture in Iran and Central Asia first. jld: Ilkhan and Timurid. Translated by Sayed Mohammad Mousa Hashemi Golpayegani. Tehran: Ministry of Culture and Islamic Guidance.

[7] Bahrami, M., (1948). Iranian industry, ceramics, Tehran University

[8] Connell, E., (2008). Islamic art, translation Houshang Taheri, Tehran: Birch.

[9] Degeorge, Gerard. Yves, Porter., (2002). The Art of the Islamic Tiles. P: Flammarion.

[10] Froom, A., (2008). Persian Ceramics from the Collection of the Asian Museums. Asian Art Museum.

[11] Fehervari, G., (1973). Islamic pottery, a comperehensive study based on the Barlow Collection, London: Faber \& Faber.

[12] Grube, E. J., (1976). Islamic Pottery of the Eight to the Fifteenth Century in the Keir Collection, London: Faber and Faber.

[13] Grube, E. J, (1976). Islamic pottery, the seventh volume of excerpts ten-volume collection of Islamic art. Nasser Khalili collection. Translation F. Haeri. Tehran: Carnegie.

[14] Kashani, A., (2007). Al-Jawahiri and costly gifts Alataybbh, Iraj Afshar. Tehran: Alma.

[15] Kambakhsh far, S., (2000). Ceramics and pottery in Iran. Tehran: Phoenix.

[16] Katly, M \& Louis Hamby., (1997). History of Iranian art. Seljuk art and Kharazmshahi. Translations Jacob Azhand, Tehran: Molly.

[17] Karbasi, C. \& F. Qayyny., (2001). Pottery enameled. Tehran: Institute of Cultural Production Department of Education.

[18] Kiani, M., (1978). Persian pottery. Iranian pottery review of prime minister. Tehran, for prime minister.

[19] Karimi, F \& Kiani., (1985). Art SfalGry Islamic period. Tehran: Iranian archeology center.

[20] Kiani, M., (2000). Pottery and SfalGry in Iran's history. Tehran: knowledge breeze.

[21] Khamoushi, L., (2006). The study of archaeological ceramics enamel (National Museum of Iran), MSc thesis, archeology, Islamic Azad University, Tehran.

[22] Pope, A., (2008). Take a look at in Iranian art. Volume IX. Tehran, Scientific and Cultural.

[23] Porter, V., (2002). Ceramic Islamic. Translation M. Shaysthfr. Tehran: Institute for Islamic Art.

[24] Pope, A., (2009). Iranian art masterpieces. Translation Khanlari. Tehran, Scientific and Cultural.

[25] Zaki, H., (2009). Iranian art in the Islamic era. Translated by Mohammad Ibrahim Eghlid. Tehran: contemporary sound.

[26] Zaki, H., (1984). Iran after the Islamic history of the industry. Translation MA Khalili. Tehran: Iqbal. 
[27] www.philamuseum.org (2015/ 10/23)

[29] www.asia.si.edu (2015/ 10/25)

[28] www.metmuseum.org (2015/10/23)

[30] National Iranian Museum (2015/ 10/ 12) 